\title{
ESTRUTURA IDEOLÓGICA E POÉTICA NO TEATRO DE GRUPO: QUAL RAZÃO PARA QUE SE CONTINUE? ${ }^{1}$
}

\author{
Vinicius Pereira (IC) \\ André Carreira (Orientador) (UDESC - CNPq)
}

RESUMO: Esta pesquisa busca compreender como a base de sustentação - constituída por certo discurso ideológico, de pensamento políticos comprometidos - repercute no pensamento estético e numa poética própria de grupos de Teatro de Grupo no Brasil. O artista parece sempre estar movido pelo questionamento dos hábitos, por isso se dão as tentativas de rompimento com a tradição; busco compreender como operam a razão própria do artista e dos grupos e como estas são projetadas para o "receptor". Como se estruturam discursos e práticas que visam certa provocação e a reação passiva ou ativa do público. Como os grupos articulam jogos de "interatividade" entre sua manifestação artística e o público. E como os conceitos ideológicos dos grupos se traduzem nos elementos subjetivos e intrínsecos à comunicação artística.

PALAVRAS-CHAVE: Teatro de Grupo; grupos de São Paulo; discurso ideológico em grupos de Teatro de Grupo; base poético-ideológica em Teatro de Grupo.

O presente trabalho aborda grupos de Teatro de Grupo no Brasil que possuam forte discurso ideológico e traça linhas que evidenciam a ideologia como elemento de sustentação de uma poética própria do grupo. Isso repercute no fato de muitos grupos praticarem a criação coletiva, como forma de explicitar questionamentos políticos comprometidos.

É realmente muito difícil definir características que delimitem o perfil daqueles grupos que realizam o que seria um Teatro de Grupo. O diretor Roberto Mallet fala que uma das características centrais deste tipo de teatro é, sem dúvida,

a idéia de continuidade e, portanto, de uma construção, vamos dizer assim, de uma identidade poética que depende também da questão do treinamento, que depende da continuidade do trabalho, enfim, acho essa uma característica fundamental. (2005)

Esta linha contínua que constrói a identidade de um grupo de Teatro de Grupo é verdadeiramente recorrente no discurso de fazedores deste tipo de teatro, ainda que as linhas estéticas variem a cada espetáculo. Alexandre Krug (2007), integrante da Companhia São Jorge de

\footnotetext{
${ }^{1}$ Projeto de Pesquisa: Áqis - Núcleo de pesquisa sobre procedimentos de criação artística CEART/UDESC. Coordenação: Prof. Dr. André Carreira. Vinicius Pereira, Bolsista Voluntário de Iniciação Científica, PIVIC, CNPq.
} 
Variedades, diz que o Teatro de Grupo é uma tábua de salvação dentro da sociedade tão massificada na qual se vive atualmente, pois para sobreviver ao mundo de mercado a única solução seria juntarse num grupo: "essa nossa peça nova fala um pouco sobre isso: dos grupos como ilhas de resistência dentro da cidade.” Sobre a linguagem estética dos espetáculos da Cia., Krug diz:

Tem sempre uma 'preocupação' épica, a gente pode até usar de um realismo [...] mas existe uma 'mente' épica por trás. De falar de problemas da atualidade, de não negar a presença do público... É muito variado, mas eu vejo uma linha de pensamento por trás, o que acaba gerando uma linguagem própria da Cia. (2007)

Cibele Forjaz (Cia. Livre) (2007) fala da continuidade como um processo de "nasceres" e "morreres", "alguma coisa que é devorada e transformada a partir de uma continuidade. [...] Existem grandes mudanças, mas que vêm da elaboração do que a gente acabou de viver. [...] Mas vendo os espetáculos se percebe que há, entre eles, uma grande coerência [que se pode chamar de estéticoideológica].” A Cia. Livre, segundo Forjaz, trabalha com grande relação entre o épico e o dramático. Outro integrante da Cia. Livre, Edgar Castro (2007), diz que trabalhar com Teatro de Grupo "é experimentar novas formas de relação, uma outra sociedade possível no aqui e agora. É não se conformar com a maneira como a sociedade se organiza, como os modos de produção se estruturam. É um laboratório de uma nova e possível sociedade.”

Este discurso de um coletivo unido por uma inquietação comum parece funcionar como base de sustentação da maioria dos grupos. Mas como isso repercute no pensamento estético do grupo? O artista parece sempre estar movido pelo questionamento dos hábitos, por isso se dão as tentativas de rompimento com a tradição. Neste aspecto, acho pertinente destacar a fala de uma integrante ${ }^{2}$ do Coletivo Filhos da Mãe... Terra, um grupo que se formou dentro do Movimento dos Sem Terra (MST):

\begin{abstract}
A nossa intenção é justamente fazer esse debate, colocar o contraponto em relação à imprensa burguesa, que coloca só de forma manipulada as notícias sobre o movimento. A gente quer mostrar que os assentamentos produzem comida, cultura e, além disso, fazer a denúncia, não só dos conflitos e da violência na luta pela terra, mas de como essa luta é desigual. Denunciar como o agronegócio está estruturado hoje no país e tentar sensibilizar as pessoas para que pelo menos elas reflitam e questionem para, quem sabe, tomar uma atitude, uma posição em relação a essas questões. (2007)
\end{abstract}

O Coletivo trabalha pesquisando textos de Bertolt Brecht, também utilizando exercícios de Augusto Boal (este estudo e apropriação técnica são feitos a partir do trabalho do Centro do Teatro do Oprimido). Na construção de seus espetáculos, o grupo diz: "a gente tenta usar instrumentos do nosso dia-a-dia, como: enxada, foice, facão; enfim, instrumentos de trabalho, mas também de luta. Essa é uma característica que tem em quase todas as peças. Que são esses instrumentos do nosso cotidiano, da realidade que a gente vive." (2007)

\footnotetext{
${ }^{2}$ Não me refiro diretamente ao nome da integrante por realmente não conseguir identificá-lo pela (precariedade da) gravação da entrevista.
} 
Os grupos têm visível influência (ou referência) do teatro brechtiano, pois traz, de certa forma, o questionamento do papel do indivíduo na sociedade capitalista. É interessante, então, ressaltar o que Walter Benjamin fala do teatro épico em relação ao público:

O tranqüilo interesse do público para o qual estão destinadas as encenações do teatro épico tem a sua especificidade exatamente no fato de que quase se apela para a capacidade de empatia do espectador. A arte do teatro épico é muito mais a de provocar o espanto ao invés da empatia. (1991, p. 215)

Em sua construção cênica, os grupos se utilizam de variadas formas para chegar a um fim que parece comum: o impacto e/ou o espanto, que seriam formas de evidenciar ao público e colocá-lo em relação com o elemento presente no momento teatral. Busca-se assim que este reflita e tome posições. Mas como isso se constrói em linguagem poética específica do grupo? Talvez a discussão ideológica esteja muito mais evidente e presente nos discursos dos grupos: o campo ideológico do grupo parece estar em primeiro plano para que, então, possa emergir, posteriormente, uma base poética própria, que esteja sempre em xeque, num limiar de discussão e reconstrução. Mesmo o "treinamento" dos grupos tem se voltado cada vez mais às cenas, fazendo percursos que vão do discurso temático para o campo poético. Segundo Gerd A. Bornheim, "Brecht nunca chegou a ponto de querer dizer: eis aqui minha Poética, é assim que deve ser. $\mathrm{O}$ forte dele está justamente no contrário dessa satisfeita aposentadoria.” (1987, p. 46)

Para Sábato Magaldi,

nos anos negros da ditadura, o exemplo brechtiano apontou para os nossos homens do palco o caminho firme da oposição ao fascismo. E ele constituiu, praticamente, uma unanimidade muito digna, através da análise lúcida apreendida nos textos maduros do dramaturgo. (1987, p. 225)

O contexto brasileiro nos anos 70 foi marcado por repressão e violência contra quem questionava o sistema político. O teatro foi grande fonte de reunião e trabalho para se pensar e produzir uma forma de reação a tal coerção política. Logo, o ideal de uma ideologia coletiva passou a ter grande valor de reconhecimento engajado no meio artístico, a alfabetização política (a troca entre palco e platéia) tornou-se peça chave de oposição à ditadura, e ao "amortecimento" massificador.

Encontro então uma discussão interessante proposta por Mallet:

No coletivo, o risco sempre é o ideológico. Você começar a não ver as coisas e repetir a ideologia que o grupo começa a ter, que o grupo começa a ver. Mas, o grupo não vê nada, quem vê são as pessoas. No fundo você tem um filtro que pode ser perigoso. Ao mesmo tempo, só é possível você encontrar uma identidade pessoal em relação com o outro. Não há 'eu' sem o outro. (2005)

Será que os grupos se formam por que tais pessoas se vêem diferentes das outras ou por que se atraem como iguais? Talvez essas relações, por uma via de mão dupla, se encontrem no Teatro de Grupo... De acordo com Pierre Bourdieu (1996, p. 334): “O verdadeiro assunto da obra 
de arte não é nada mais que a maneira propriamente artística de apreender o mundo, isto é, o próprio artista, sua maneira e seu estilo, marcas infalíveis do domínio que tem de sua arte." No âmbito do Teatro de Grupo, a criação ligada ao coletivo tem se dado a partir da relação de um tema (texto ou pré-texto) e o grupo de atores, com perceptível vontade de diálogo e de proximidade com o público, muitas vezes desde o processo de criação, irradiando do espetáculo para a extensão social.

A própria constituição do grupo parece ser um microcosmo do que se deseja como sociedade. Então o grupo tenta se organizar em uma estrutura à margem da cultura de massa, e entra em embate com relação à divisão de tarefas, a busca por uma criação que preze o coletivo, a conquista e a manutenção de um espaço (sede), os deveres administrativos, etc. Percebo nas falas destes grupos a evidência de um projeto social, certa vontade de modificação ou incitação ao outro (ao espectador, à comunidade). Mas como se consolida o projeto interno do grupo, de seus gestores? Será que esta reunião de trabalho não gera uma reorganização nos próprios indivíduos do grupo? O Coletivo Filhos da Mãe... Terra diz:

A gente acredita que a cultura que se quer é diferente dessa cultura que está aí fora, na sociedade. E a gente busca uma coisa justamente diferente disso. Então, participamos do grupo, mas nos vários espaços do Movimento estamos em constante formação. Participamos de cursos, de seminários, congressos. Então acreditamos que a grande escola é o MST. [...] Tem essa coisa do Movimento, de apostar em um processo de formação contínua que é onde a gente analisa as produções, dentro do que estamos desenvolvendo. Tentando analisar criticamente, de fato, não passando a mão na cabecinha. Só porque a gente faz é bom? Não é. Precisa ter qualidade, levar a alguma coisa. Não é simplesmente apresentar e sair fora, precisa trazer algo além. (2007)

É bem definida a tomada de posição crítica não somente dos fatos externos ao grupo, à sociedade como vista de fora, mas também a autocrítica, o processo de revisão e questionamento constante. É claro que no caso do Coletivo os ideais do MST são evidentes e declarados, existe uma força que visa ao objetivo do Movimento. Porém, mesmo ligados a um movimento, existem posições divergentes que precisam entrar em diálogo com quem faz teatro e quem o assiste. A experiência do Coletivo explicita a questão do diálogo quando eles apontam para um caso de conflito:

\footnotetext{
teve uma vez que apresentamos em um assentamento em Itapeva [...] e a reação de algumas pessoas foi totalmente contrária ao que fazíamos, elas saíram inclusive no meio da peça, porque eles eram alunos de uma faculdade em Piracicaba, eu acho, que estuda essa questão do agronegócio. (2007)
}

Então, o teatro acaba sendo uma forma de propor discussão sobre a própria ideologia do grupo, pois existe uma razão do artista e do grupo que é projetada para o "receptor", e para o grupo é interessante e importante o retorno desse pensamento, articulando jogos de "interatividade" entre sua manifestação artística e o público. 
Uma vez que o campo ideológico dos grupos se traduz nos elementos subjetivos e intrínsecos à comunicação artística, e da constante reestruturação poética desta, o Teatro de Grupo parece entrar em embate com o ambiente social (econômico e político) em que vivemos. As pessoas inseridas nestes grupos parecem questionar os valores de individualização, de hierarquia, o poder de coerção e exploração, aquilo que em primeira instância seria exterior ao grupo, ou seja, o sistema capitalista, a sociedade de massas. Mas ao mesmo tempo discutem as relações internas (pela ruptura de valores pontuais, internalizados em cada um pelo convívio social vigente). Neste sentido é interessante observar que ao ser questionado sobre o que é fazer Teatro de Grupo, Alexandre Krug fala:

\begin{abstract}
É tentar viver a utopia de uma organização coletiva, democrática. É tentar pôr em prática o ideal de uma vida criativa. Porque é diferente quando o grupo gira em torno de um diretor que define tudo. No Teatro de Grupo, todos os membros se organizam de forma coletiva e todos têm voz... E isso de se organizar coletivamente é muito difícil; tem a convivência dos egos... (2007)
\end{abstract}

A organização coletiva no Teatro de Grupo demanda uma reorganização do mundo do indivíduo, para que se possa enxergar alternativas ao que se tem naturalizado como padrão social. Mas esta revisão dos valores referenciais, estes discursos e práticas que visam certa provocação e a reação passiva ou ativa do público, querem colocar o padrão em segundo plano (ou até anulá-lo) ou sugerir uma via alternativa, um outro modelo?

Para terminar, preciso deixar clara a minha não-intenção de analisar o teatro de Brecht (ou mesmo de Boal) no âmbito brasileiro, para tal estudo demandaria um maior tempo. Meu principal objetivo é estabelecer um passo inicial em minha pesquisa sobre teatro de grupo. Outrossim, não é meu foco estabelecer julgamento de valor ideológico sobre a produção teatral. O que ocorre é que os discursos ideológicos destes grupos de Teatro de Grupo se aproximam e dialogam com aquele desenvolvido e explorado por Brecht. A própria tentativa dialética, a busca pela ruptura e a vontade de um teatro lúcido se alinhavam nas palavras que reúnem em grupos específicos. Da mesma forma, a constituição de um grupo deste tipo, com um pensamento que une cada pessoa naquela formação coletiva (com certa estabilidade), traz a vontade de criação a partir dos outros, dos questionamentos da própria relação interna do grupo, envolvendo-o em certo processo dialético. 


\section{Referências}

BENJAMIN, Walter. O que é o teatro épico? In: BENJAMIN, Walter; KOTHE, Flávio R. (org.). Walter Benjamin: sociologia. $2^{a}$ ed. São Paulo: Ática, 1991. pp. 212-8

BORNHEIM, Gerd A. Os pressupostos gerais da estética de Brecht. In: BADER, Wolfgang (org.). Brecht no Brasil: experiências e influências. Rio de Janeiro: Paz e Terra, 1987. pp. 45-53 BOURDIEU, Pierre. As regras da arte: gênese e estrutura do campo literário. São Paulo: Companhia das Letras, 1996. 431p.

CASTRO, Edgar. Entrevista ao ÁQIS - Grupo de pesquisa. <http://aqis.ceart.udesc.br>. (2007) COLETIVO FILHOS DA MÃE... TERRA. Entrevista ao ÁQIS - Grupo de pesquisa.

$<$ http://aqis.ceart.udesc.br>. (2007)

FORJAZ, Cibele. Entrevista ao ÁQIS - Grupo de pesquisa. <http://aqis.ceart.udesc.br>. (2007) KRUG, Alexandre. Entrevista ao ÁQIS - Grupo de pesquisa. <http://aqis.ceart.udesc.br>. (2007) MAGALDI, Sábato. O papel de Brecht no teatro brasileiro. In: BADER, Wolfgang. Brecht no Brasil: experiências e influências. Rio de Janeiro: Paz e Terra, 1987. pp. 223-5

MALLET, Roberto. Entrevista ao ÁQIS - Grupo de pesquisa. <http://aqis.ceart.udesc.br>. (2005) 